\title{
Popular Music Studies in the Low Countries: Status Quo Vadis IASPM Benelux
}

\author{
Melanie Schiller \\ University of Groningen \\ IASPM Benelux executive board member and national \\ representative \\ m.m.schiller@rug.nl
}

\section{Introduction}

Considering that the First International Conference on Popular Music Research (organized by Gerard Kempers) (1) was held in Amsterdam in June 1981, and as a result of which IASPM was founded, it can be said that the Benelux have been fundamental to the association's establishment and subsequent international growth from the very beginning (Tagg 2005). The local Benelux branch was established three years later (and officially registered at the chamber of commerce in 1987), which makes it one of the oldest local branches of the association. Since its early days, the branch and its members have always been active in international contexts and discourses, with a deep understanding of the transnational and transcultural character of popular music as cultural practice and as an object of academic study. Since the beginning, the aim has been to connect people involved in the study of popular music from different countries, disciplines, and professions - goals the IASPM Benelux branch is still committed to. This international orientation and transdisciplinary character of the branch is ideologically grounded but also pragmatically motivated; considering the size of the region, its geographic location, and the small scope of academics involved in popular music research in the Low Countries, exchanges beyond national, institutional and professional boundaries are essential for the field of popular music studies in the Benelux. 


\section{Status Quo}

Since the turn of the century the branch has organized several international branch conferences in Amsterdam (2001), Haarlem (2010), Rotterdam (2014), in collaboration with the francophone branch in Luik (2015), and it is currently preparing the upcoming conference in Antwerp on the topic of "RE-peat, please" scheduled to take place in May 2020. Besides these larger events and involvement in other IASPM activities like the 2017 international conference in Kassel and reviewing articles for IASPM Journal, the branch regularly organizes smaller workshops, study days and one-day symposia on specific topics like: "Dance Music and the Creative City" (Groningen 2011), "Sound, Gods and the Nation" (Amsterdam 2012), "Sonic Territories: POP and THE CITY" (Amsterdam 2013', "the local and the global in cultures of popular music" (Groningen 2014), or "Festival Cultures" (Groningen 2015) to name but a few. An important milestone for the Benelux branch was certainly also the publication of the volume Made in the Low Countries in the Routledge Studies in Popular Music series, edited by Lutgard Mutsaers and Gert Keunen (2017).

One of the priorities of the Benelux branch has been supporting and inspiring the young generation of popular music researchers. To that end, the branch has started a new conference series in 2016: the annual IASPM Benelux student conference (Groningen 2016, Amsterdam 2017, Rotterdam 2018, Utrecht 2019), which is organized in close collaboration with students to offer the next generation of popular music scholars valuable experiences in conference organization and participation, in presenting their work, receiving feedback and engaging in academic networking and exchange. Another cornerstone in promoting the study of popular music in the region has been the annual Popular Music Thesis Prize for the best Bachelor and Master thesis about popular music written in the Netherlands, awarded by a jury of music professionals, journalists, and academics from different disciplines; until 2016 awarded in collaboration with the Royal Society for Music History (KVNM), and since 2017 with the Association of Dutch Music Venues and Festival (VNPF).

\section{Popular music research and studies in the Benelux}

Popular music studies in the Benelux region (as elsewhere) has always been closely connected with individuals dedicated to advancing the field. IASPM therefore remains one of the central hubs for connecting scholars working in popular music from different perspectives and disciplines and in diverse institutional settings and study programs ranging from musicology, music education, media studies, sociology, American studies, European studies, and globalization studies to political science, psychology and law - largely at universities and to a certain degree at music conservatoires. Despite the fact that popular music is occasionally the object of study in such a wide range of disciplines, academic popular music curricula are still scarce and research on the topic remains fragmented, with individuals researching popular music-related themes all across the region: like Linda Duits' and Koos Zwaan's work on fan cultures in Utrecht and Haarlem (Duits et al. (eds.) 2014) as well as Tom ter Bogt in Utrecht who has published extensively on popular music taste and youth culture, functions of music listening and effects of music on adolescence from sociological, quantitative empirical and behavioral psychology perspectives (Bogt 2006, Harakeh and Bogt 2018). A few locations and institutions, however, have established themselves as centers for popular music 
studies and research in the Netherlands and (the Dutch-speaking regions of) Belgium.

\section{Amsterdam}

Teaching and research on popular music at the University of Amsterdam is - typical for the field - spread across different faculties, disciplines, and study programs, with particular expertise in (cross-)media and cultural studies, sound, globalization, and celebrity culture at the media studies department, and the music department which offers students three perspectives: historical, cultural, and cognitive/computational musicology. Within the cultural musicology curriculum, courses pay attention to different forms of popular music and practices with specific staff expertise in musical traditions from the Middle East, European and North American art music traditions of the past two centuries, East Asian and South African music, Indonesian music, and jazz worldwide. As these core areas indicate, the main fields of research and teaching in cultural musicology in Amsterdam include ethnomusicology with a methodological focus on ethnography. Whereas computational and cognitive musicology focuses on general questions of human evolution and music(ality) (Henkjan Honing 2018, 2019) or memorability of melodies and rhythm complexity (Brouwer et. al. 2017, Janssen et. al. 2018), it might at times also work with popular music-related projects for instance relating to Spotify. Current research themes in musicology in Amsterdam include: popular music practices in post-apartheid and the historiographical implications of South African maskanda music (Barbara Titus, forthcoming), German popular music studies (Oliver Seibt et. al. (eds.) forthcoming) and the concurrence of the dimensions of "the real", "the fictive", and "the imaginary" in music cultures as the recent conference "'Elvis lives in Amsterdam" manifestations of the imaginary musician" exemplifies (Rutger Helmers and Oliver Seibt 2018); and importantly, Walter van der Leur's work on Jazz and the forthcoming The History of Jazz in Europe and Jazz and Death: Rituals and Representations. Current themes in media studies research on popular music in Amsterdam include: U.S. American Black Female Superstardom and star text analysis (Jaap Kooijman 2019), historical research on the Dutch music TV channel The Music Factory (ibid. 2017) and music and platformization in China from a new media perspective (Jeroen de Kloet) as well as a cultural geography of folk music and the articulation of the local in China (ibid.).

\section{Groningen}

Popular music studies in Groningen is primarily embedded in the music specialization of the Arts, Culture and Media Bachelor program and, at Masters' level, in the music track in the Music, Theatre and Performance Studies program at the University of Groningen. These curricula are interdisciplinary in design and focus on analytical, historical, and critical theoretical understanding of (popular) music and its performative, mediated, and discursive formations. As such, popular music studies in Groningen is firmly rooted in the humanities with an emphasis on critical cultural theory and analysis, drawing in particular from the disciplines of cultural studies, ethnomusicology, musicology, sound studies, media studies, postcolonial studies and theories of race, gender, sexuality, and ethnicity. Main and emerging research topics in Groningen include improvisation in training and educational networks in Europe, gender dynamics in the music industry, contemporary European Jazz Culture (Kristin McGee 2019) and Beyoncé studies (ibid. 2019a and 2019b); theorizing vocal performance and reception of free jazz voice (Chris Tonelli 2019), theorizing mimesis in popular music and transnational 
flows of popular music like the consumption of Japanese popular music outside of Japan, and music in video games (ibid.); as well as work on German popular music and national identity negotiated in music like cabaret (Melanie Schiller 2019), Schlager, Beat, Kraftwerk, Rammstein and Techno (ibid. 2018), irony and framing, and popular music and nationalism, the new right and the rise of populism in Europe and Sweden in particular (Melanie Schiller). Other research includes the influence of Jewish music in American popular songs (Niels Falch), European popular music festivals (Rob Ahlers) and work on disembodied voices in electronic music (André Arends). Additionally, the University of Groningen offers programs in media studies, digital humanities and journalism, where popular music might be an object of study with more focus on communication theories, technology and creative industries, and research on algorithms, datafication and music streaming platforms such as Spotify's role as an intermediary in the music industry (Robert Prey, Marc Esteve, Leslie Zwerver and Dimitris Soudis).

\section{Rotterdam}

Popular music studies in Rotterdam is primarily located in the research cluster Music, Industry, Culture \& Society (MICS) and the department for Arts and Culture Studies at the Erasmus University Rotterdam, and it is strongly embedded in the sociological tradition. Research on popular music in Rotterdam focuses on the socio-economic, socio-cultural and spatial contexts in which cultural practices take place and positions itself in cultural sociology, cultural economics/management and culture studies. Students of Arts and Culture are offered courses in social science methods and quantitative social scientific research, statistics and qualitative research methods, economic theory applied to the cultural sector and the creative industries, and marketing and entrepreneurship. Erasmus University Rotterdam also offers a Media and Communication program, with more emphasis on communication and media scholarship including media systems, media entertainment \& popular culture, technologies, and new media production. Current research in Rotterdam is primarily connected to these units and includes a wide variety of themes: popular music heritage, cultural memory and identity (Susanne Janssen, Arno van der Hoeven and Amanda Brandellero), legitimation, consecration and the evaluation of music (Alex van Venrooij), professionalization and institutionalization like the research project on sustainable live music ecologies for artists, music venues and cities in collaboration with the Rotterdam University of Applied Sciences (Erik Hitters, Pauwke Berkers and Paul Rutten), globalization (Marc Verboord), and social inequalities exemplified by Pauwke Berkers' and Julian Schaap's work on gender in metal music production (2018), whiteness in rock (Julian Schaap) and diversity at music festivals (Pauwke Berkers and Britt Swartjes), or Femke Vandenberg's research on popular music consumption and class in Rotterdam. Research in the field of popular music and cultural studies in Rotterdam includes fan studies on K-Pop and boybands (Simone Driessen) and work on music and tourism (Leonieke Bolderman). Finally, economists and management scholars at Erasmus University Rotterdam study technological change, cultural and creative industries and copyrights issues in music (such as Christian Handke) and entrepreneurship among musicians (such as Ellen Loots). 


\section{Belgium/Flanders}

The Benelux branch unites scholars from the Netherlands, Flanders and the Dutchspeaking region of Belgium, while Wallonia, Belgium's French-speaking region, is part of the Francophone d'Europe branch. The small Grand Duchy of Luxembourg, although included in the branch's name, has been mostly absent from the popular music studies discourse, and most popular music researchers are active within academic institutions in the Netherlands. In Flanders, however, research on popular music is gradually gaining traction, but much work is still done in relative isolation. This is in part due to the underrepresentation of popular music in higher education institutions. While all four Flemish conservatoires (which are part of university colleges) comprise jazz departments, only one, KASK \& Conservatorium in Ghent, offers popular music courses. In most conservatoires, performance-based (or artistic) research is being undertaken, albeit primarily with a jazz emphasis, and mainly at MA level. In addition, one other university college, PXL in Hasselt, has a dedicated pop department that has for a few years maintained a small research unit, PXL-MUSIC Research. Its primary focus lies on applied research and data science in the music industry (Jonas Kiesekoms), for which it collaborates with Poppunt, a support centre for performers that also has a mission to sustain (quantitative) research, primarily relating to policy and big data. Other projects at PXL include Gert Keunen's work on Belgian popular music history and industry (Keunen 2013, 2015). Furthermore, a number of Flemish universities have departments where research on popular music is conducted from different perspectives and disciplines, albeit often by individual scholars rather than research groups or clusters. Neither of the two musicology departments at Ghent University and KU Leuven embrace research invested in popular music, but at other departments in these and other universities, individual researchers work on particular aspects of popular music, such as gender and media, fandom and the role of music in LGBTQ+ communities (Marion Wasserbauer) as well as jazz competitions, historical recreation in popular music at the University of Antwerp, policy and AI (KU Leuven), or queer theory, diversity and LGBTQ+ representation (Frederik Dhaenens) and Adorno, philosophy of music practice (Carlos Roos) at Ghent University. Because of this fragmented environment, Flemish researchers often employ the Benelux branch as a virtual community, and are active in the branch through representation on the board, through their presence at local and international conferences, and through membership. We hope that the upcoming international Benelux branch conference "RE-peat, please," organized at the University of Antwerp in 2020 (Matthias Heyman), will be another important impulse to further institutionalize popular music research in Flanders.

\section{Quo Vadis?}

Although IASPM Benelux has always been internationally oriented, the internationalization of the branch has gained substantive traction in the last decade. Parallel to similar developments in the academic world in general and popular music studies in particular, the increasing (expectation of) international mobility of researchers has led to ever more diverse faculties. The IASPM Benelux executive boards of the last decade for instance consisted of members hailing from the USA, Canada, Germany, and, of course, Belgium and the Netherlands. While this ongoing change may bear the potential for contention due to cultural differences, communication styles, and diverging understandings of acting roles and hierarchies, it does also foster constructive debates and improve sensibilities for 
diversity, inclusion and intercultural dialog; all of which have been aims of IASPM since the beginnings, albeit its inherent Anglocentrism. One indicator for this ongoing change is then also the switch in operational language from Dutch to English, which mirrors very similar developments at universities, as most popular music related study programs in the Benelux have switched from Dutch to English language education in the last decade or so, to be able to compete in the international market of higher education.

When looking at the history of the branch it can be noted that since its official registration in 1987, the executive boards have had only six female members over the decades, compared to seventeen men; with four male chairs (Stan Rijven, Hans Walraven, Tom ter Bogt and Oliver Seibt) compared to two women (Lutgard Mutsaers and Kristin McGee). This may not adequately reflect the gender balance of the entire field of popular music studies in the Benelux, but it does point to the continuous systemic disadvantaging of women (2) when it comes to career development, promotions, and advancing to positions of power in academia (and elsewhere). Hopefully in the future IASPM Benelux can further improve its own understanding of - and role in - working towards a more equal and inclusive field of popular music studies.

An important challenge for popular music studies in the Benelux (and elsewhere) has always been (the lack of) funding, however there is reason to believe that this situation might deteriorate rather than improve in the near future. The Dutch government has for a long time been pursuing a rigorous austerity politics when it comes to higher education and scientific research, with even more budget cuts planned. These politics have already led to a systematically underfunded system resulting in, amongst other things, unhealthy work pressure, structural overtime, and high rates of physical and mental illnesses amongst university faculties (for a summary of recent surveys and research on the topic see: WOinActie 2019). In this context, funding for arts and culture studies has continuously and substantially diminished while the number of students has disproportionally increased, and only recently the Dutch and Flemish governments have announced further plans to reallocate more funds away from social sciences and humanities towards STEM institutions.

Finally, this already worrying development is intensified by a political climate in Europe and the Benelux that increasingly questions the value of the very existence of subjects, disciplines and study programs that are closely connected with popular music, such as gender- and post-colonial studies. Right-wing populists in the Netherlands have long been agitating against what they depreciatively call pretstudies ("fun studies") such as arts and humanities subjects, against "leftist hobbies" like arts and culture in general, and against an alleged linkse indoctrinatie ("leftist indoctrination") at universities and particularly social science and humanities departments. The latter has now resulted in an online registration system where pupils and students are to denunciate their educators for unwanted ideological content, set up by the Renaissance Institute for research and education of the far-right populist Thierry Baudet's Forum for Democracy.

When the first IASPM conference was held in Amsterdam in 1981, the Netherlands had become known for its leftwing grassroots movements, its pacifism, and environmentalism (Mutsaers and Keunen 2017: xxvi): it was this atmosphere that had attracted the first generation of "IASPM-ites" to Amsterdam to set up an association that should transcend national, disciplinary, and professional boundaries to take popular music as "the music of most people" seriously (Tagg 2001). Today, almost 40 years later, although in a very different political and 
academic climate, IASPM Benelux is still struggling with widespread austerity measures and financial hardships (cf. Tagg 1983) and trying to stand up for democracy and equality as in the early days (cf. Tagg 2011). The newly elected executive board of the Benelux branch (Oliver Seibt, chair, Chris Tonelli, secretary, Femke Vandenberg, treasurer and membership secretary, Matthias Heyman, communications, and Melanie Schiller, general member and national representative) will also do its best to continue defending these fundamental values, academic freedom, and the study of popular music in all its facets.

\section{Endnotes}

(1) Gerard Kempers was the local organizer; the conference was arranged in collaboration with David Horn and Philip Tagg.

(2) Not to mention non-binary people and people of color.

\section{Acknowledgements}

I have to thank (in alphabetical order) Pauwke Berkers, Jeroen de Kloet, Matthias Heyman, Jaap Kooijman, Kristin McGee, Oliver Seibt, Barbara Titus, and Chris Tonelli for their invaluable input for this article.

\section{Bibliography}

Baade, C. et al. Eds. Making Lemonade: Finding Art, Activism, and Community with Beyoncé in Troubled Times. Middletown: Wesleyan University Press. (forthcoming).

Berkers, P. and J. Schaap. 2018. Gender inequality in Metal Music Production. Bingley: Emerald Publishing.

Bogt, T.F.M. ter. 2006. (Un-)Cool. De structuur van de muzieksmaak. Den Haag: Haagse Hogeschool.

Bouwer, F. L. et. al. 2018 . What makes a rhythm complex? The influence of musical training and accent type on beat perception. PLOS ONE 13(1). https://doi.org/10.1371/journal.pone.0190322

Duits, L. et.al. Eds. 2014. The Ashgate Research Companion to Fan Cultures. Farnham.

Harakeh, Z. and ter Bogt, Tom F.M., 2018. The Effect of Rap/Hip-Hop Music on Young Adult Smoking - An Experimental Study. Substance Use and Misuse 53(11): 1819-1825. https://doi.org/10.1080/10826084.2018.1436565

Honing, H. 2018. The Origins of Musicality. Cambridge: MIT Press.

2019. The Evolving Animal Orchestra. In Search of What Makes Us Musical. Cambridge: MIT Press.

Janssen, B. et. al. 2017. Predicting Variation of Folk Songs: A Corpus Analysis Study on the Memorability of Melodies. Frontiers in Psychology 8(621]). https://doi.org/10.3389/fpsyg.2017.00621

Keunen, G. 2015. Een eeuw popmuziek. Van Crooners tot Dubstep. Tielt: Lannoo. 2013. Alternative mainstream. Tielt: Lannoo. 
Kooijman, J. -

2017. I Want My MTV, We Want Our TMF: The Music Factory, MTV Europe, and Music Television in the Netherlands, 1995-2011. VIEW Journal of European Television History and Culture 6 (11): 93-101. http://doi.org/10.18146/2213-0969.2017.jethc126

2019. Fierce, Fabulous, and In/Famous: Beyoncé as Black Diva. Popular Music and Society 42 (1): 6-21. http://dx.doi.org/10.1080/03007766.2019.1555888

Leur, W. van de. -

Ed. The History of Jazz in Europe. Oxford: Oxford University Press. (forthcoming) Jazz and Death: Rituals and Representations. London: Routledge. (forthcoming) McGee, K. -

2019a. Biopolitics and Media Power in the Online Dance Remake: Remixing Beyoncé's "***Flawless" in the YouTube Archive" In K. McGee et. al. (Eds.) Special Issue on Beyoncé In Popular Music and Society 1(42): 2241. https://doi.org/10.1080/03007766.2019.1555891 2019b. Remixing European Jazz Culture. London: Routledge.

Mutsaers, L. and Keunen, G. Eds. 2017. Made in the Low Countries. London: Routledge.

Mutsaers, L. and Keunen, G. 2017. Introduction: Together Apart: Popular Music in the Low Countries: This the Flow and against the Odds. In Mutsaers, L. and Keunen, G. Eds. Made in the Low Countries. London: Routledge: xx-xxviii Schiller, M. -

2018. Soundtracking Germany: Popular Music and National Identity. London: Rowman and Littlefield.

2019. Staging the nation: Claire Waldoff and Berlin cabaret before and during the Great War. In J. Mullen Ed. Popular Song in the First World War: An International Perspective. Routledge, London.

Tonelli, C. 2019. Voices Found: Free Jazz \& Singing. London: Routledge.

Seibt, O. et. al. Eds. Made in Germany. London: Routledge (forthcoming).

Tagg, P. -

1983. "Why IASPM? Which Tasks?" https://tagg.org/articles/iasptask83.html Accessed: 9 November 2019.

2001. "Twenty Years After. Speech delivered by Philip Tagg at Founder's Event, 11 th International IASPM Conference, Turku, 8 July 2001." https://tagg.org/articles/turku2001.html\#pgfld-303307 Accessed: 9 November 2019.

2015. "Personal Statement" https://tagg.org/zmisc/GKobit1.htm Accessed: 9 November 2019.

Titus, B. "Your Tongue, Your Sound, Your Song from Your Inside:" Hearing Maskanda in Post-Apartheid South Africa. (forthcoming)

WOinActie. 2019. The Effects. https://woinactie.blogspot.com/p/theconsequences.html Accessed: 9 November 2019. 